\title{
Enhancement and Prolongation of Babesia microti Infections in Mice Infected with Oncogenic Viruses
}

\author{
By F. E. G. COX \\ Department of Zoology, King's College, Strand, London, WC2R $2 L S$ \\ AND NINA WEDDERBURN \\ Royal College of Surgeons, Lincoln's Inn Fields, London, WC2 ${ }_{3} P N$
}

(Accepted for publication I8 March 1972)

\begin{abstract}
SUMMARY
The intraerythrocytic piroplasm, Babesia microti, causes a self-limiting infection in Balb/c mice; parasitaemia is maximal (about $30 \%$ ) at 12 days and from I to 6 months after infection parasites are seldom seen in the blood. In mice concurrently infected with either of the lymphomagenic viruses Rowson Parr Virus (RPV) or ULV, a virus isolated from a urethane induced leukaemia, $B$. microti parasitaemias reached over $60 \%$ and remained patent until the experiment was terminated at 6 months. Prolonged patent parasitaemias were higher in mice infected with ULV. Antibody levels to the piroplasm, estimated by an indirect fluorescent antibody technique, were similar in mice with and without viral infections. There was no evidence of increased lymphomagenesis in doubly infected animals.
\end{abstract}

\section{INTRODUCTION}

Infections with intraerythrocytic protozoa both affect and are affected by other agents. Most observations on these interactions have been made on infections with malaria parasites, but the general principles involved may be applicable to the other main group of intraerythrocytic protozoa, the piroplasms. The intensity of infections with Plasmodium berghei berghei is reduced by prior or simultaneous infection with, for example, Eperythrozoon coccoides (Peters, 1965, and others), West Nile Virus (Yoeli, Becker \& Bernkopf, 1955) and Newcastle Disease Virus (Jahiel, Nussenzweig, Vanderberg \& Vilcek, I968; Schultz, Huang \& Gordon, 1968). Eperythrozoon coccoides also has an antagonistic effect on infections with Plasmodium vinckei vinckei (Cox, 1966), $P$. vinckei chabaudi (Peters, 1967) and Babesia rodhaini (Peters, 1965). On the other hand, the Rowson Parr virus (RPV) which was isolated from Friend virus by end-point dilution (Rowson \& Parr, 1970) and ULV, a lymphomagenic virus isolated from a urethane-induced lymphoma (Salaman, I963; Salaman \& Flocks, I964), enhance $P$. berghei yoelii infections in Balb/c mice (Salaman \& Wedderburn, I969; Salaman, Wedderburn \& Bruce-Chwatt, 1969).

Babesia microti, a common and widespread parasite of small mammals which can infect monkeys (Shortt \& Blackie, 1965) and humans (Gleason et al. 1970) can be adapted to mice (Cox \& Young, 1969). After the inoculation of infected blood, the parasitaemia reaches a peak (at which about $30 \%$ of the red blood corpuscles are infected) I2 days later, after which the parasites disappear from the blood during the 3 rd or 4 th week after infection. Occasional natural recrudescences at very low levels and recrudescences after splenectomy may occur during several months after the original disappearance of parasites from the blood.

The experiments described in this paper are concerned with the effects of RPV and ULV on Babesia microti infections in mice. 


\section{METHODS}

Mice

Balb/c mice, maintained by brother-sister mating, were fed a pellet diet, Diet $4 \mathrm{IB}$ (W. Lillico and Sons, Betchworth, Surrey) and water ad lib.

\section{Viruses}

Rowson Parr Virus (RPV). Citrated plasma from infected mice was inoculated intravenously. Each dose of $0 \cdot 1 \mathrm{ml}$ contained $10^{3}-\mathrm{IO}^{4} \mathrm{LD}_{50}$.

Urethane Leukaemia Virus (ULV). This virus is transmissible by infection or spontaneously from parent to offspring (vertically). Balb/c mice were infected neonatally and then used for breeding. This vertically transmitted line has been maintained for 18 generations without significant alteration in the incidence of lymphomas which develop after 5 to 12 months. Spontaneously infected mice were used in these experiments.

\section{Babesia}

The King's 67 strain of Babesia microti used in this study was originally isolated:from a vole, Microtus agrestis, and established first in rats and later in mice. The strain was passaged weekly by intraperitoneal inoculations of infected blood in Alsever's solution $(\mathrm{NaCl}$, $0.525 \mathrm{~g}$; Na citrate, $1.0 \mathrm{~g}$; glucose 2.33 g; distilled water, $100 \mathrm{ml}$ ). Mice were infected intraperitoneally with $1 \cdot 25 \times 10^{6}$ parasitized red blood cells in $0.4 \mathrm{ml}$ Alsever's solution. Infections were monitored by taking blood from a tail vein and estimating the parasitaemia as a percentage of the red blood cells infected in thin films stained with Giemsa's stain.

\section{Immunological techniques}

Antibody levels to Babesia microti were estimated using a fluorescent antibody technique. Thin blood films containing $B$. microti were made, dried, fixed in $0.3 \mathrm{~N}-\mathrm{HCl}$ for $5 \mathrm{~min}$ and washed. Serial dilutions of test sera were applied for $30 \mathrm{~min}$ at room temperature. After staining with fluorescein labelled rabbit anti-mouse immunoglobulin for $30 \mathrm{~min}$, slides were rinsed in Evans blue, mounted in glycerol and examined under ultraviolet light using a Zeiss microscope (Cox, Crandall \& Turner, 1969).

\section{Experimental procedure}

Experiment I. Four groups of six 8-week-old male Balb/c mice were treated as follows. Group I received Babesia microti on day 0 , group 2 received RPV on day -5 and $B$. microti on day 0 ; group 3 received RPV immediately before $B$. microti on day 0 and group 4 , already carrying ULV, received $B$. microti on day 0 . All mice were examined at first every 2 days and then weekly for piroplasms; after 6 months they were killed and their organs examined for evidence of lymphoma.

Experiment 2. Three groups of six 8-week-old female Balb/c mice were treated as follows. Group I received Babesia microti on day o, group 2 received B. microti and RPV on day o, and group 3 received RPV alone. Two groups of ULV-infected male mice were also used. Group 4 received B. microti on day o and group 5 was used as a control. Samples of blood were taken from all these mice for immunological analysis 7 and 14 days after infection with B. microti. 


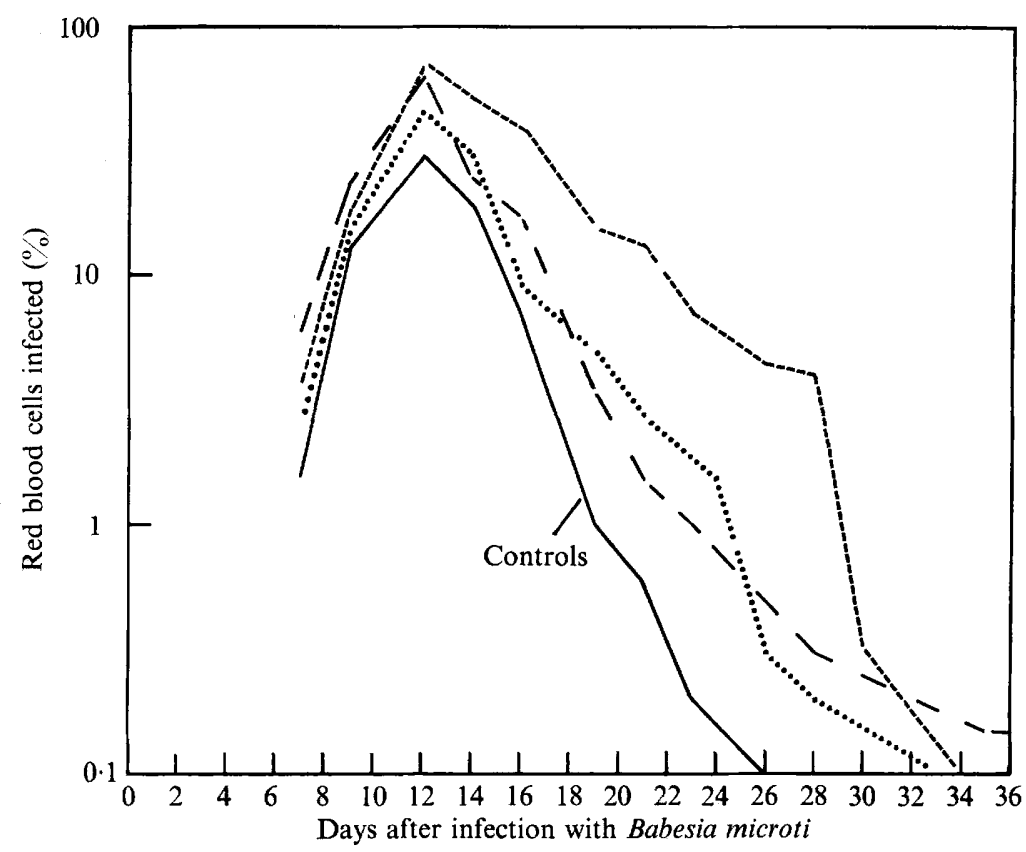

Fig. I. Patterns of parasitaemia in mice infected with Babesia microti, B. microti and RPV or $B$. microti and ULV during the first 5 weeks after infection. Each point is the average from six mice, plotted on a 3-cycle logarithmic scale. B. microti alone, $-; B$. microti and RPV on day $-5, \ldots \ldots$; $B$. microti and RPV on day $0, \ldots ; B$. microti and ULV, $-\ldots \ldots$.

\section{RESULTS}

Patterns of Babesia microti infections. The patterns of parasitaemia in Expt $\mathrm{I}$ are shown in Fig. I and 2.

Parasitaemia was maximal on day 12 in all groups, but the peak levels reached in the virusinfected mice were higher than those in the control group infected with Babesia microti alone and, while the former mice were hunched and fluffed for several days, the latter appeared healthy.

In the control group occasional parasites were seen over the next 5 months, but never more than one or two parasites in the blood film of a single mouse.

In the doubly infected mice, parasitaemia declined more slowly than in control mice, and no mouse was completely aparasitaemic during the course of the experiment. In particular, parasitaemia in the ULV-infected group persisted at a higher level than in either of the other infected groups and individual parasitaemias of up to $20 \%$ were observed in these mice for as long as 6 months after infection (Fig. 2). There was no evidence of any cyclical pattern of recrudescence in any group.

The results obtained in the second experiment were consistent with those in the first, namely an increase in the level and duration of parasitaemia in the virus-infected mice compared with the control animals.

Antibody levels. The antibody levels in the mice in the second experiment are shown in Table I. Titres in virus-infected animals were not significantly different from those in mice infected with Babesia microti alone.

Pathology. Animals infected with Babesia microti only, and killed at the time of peak 


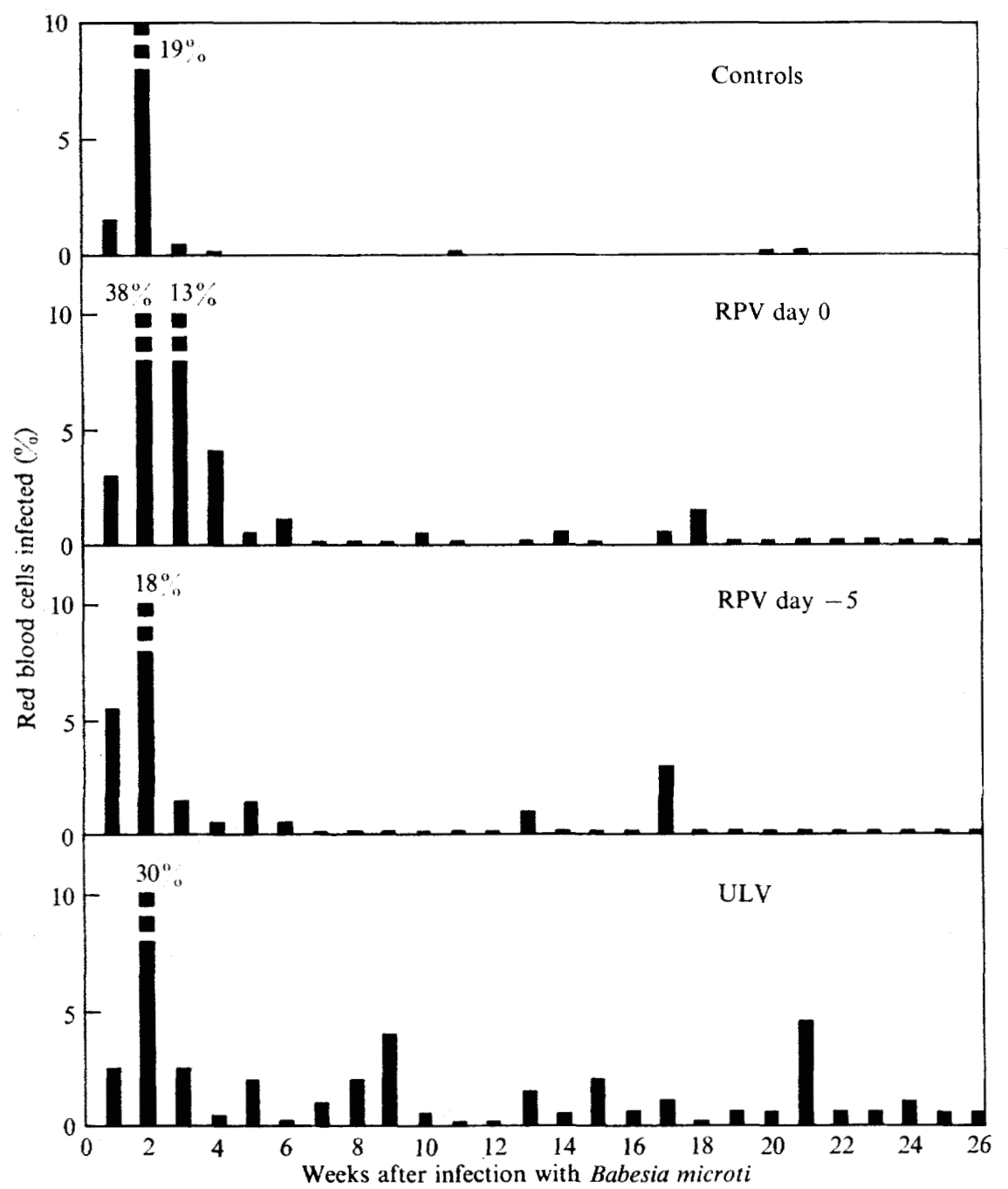

Fig. 2. Parasitaemia in mice infected with Babesia microti, B. microti and RPV or B. microti and ULV over a period of 6 months after infection. The high parasitaemias at 2 weeks (see Fig. I) have all been reduced to $10 \%$ for clarity. (Arithmetic scale.)

Table I. Antibody titres in mice infected with Babesia microti, B. microti and $U L V, B$. microti and RPV, RPV or ULV

Each figure represents the reciprocal of the antibody titre determined from the pooled sera of six mice using an indirect fluorescent antibody technique.

$\begin{array}{lrr}\text { B. microti }+ \text { RPV } & 7 & 14 \\ \text { B. microti }+ \text { ULV } & 40 & 320 \\ \text { B. microti } & 80 & 320 \\ \text { RPV } & 40 & 160 \\ \text { ULV } & - & 0 \\ \text { Babesia microti }\end{array}$


parasitaemia, II or I 2 days after infection, had spleens weighing between 0.4 and $\mathrm{I} \cdot 0 \mathrm{~g}$. There was considerable hyperplasia of the red pulp with erythropoiesis and an increase in reticulum cells. Lymphoid follicles were also enlarged and contained active germinal centres, cells in mitosis and tingible bodies. The livers showed islands of erythropoiesis and the sinusoids were infiltrated with polymorphonuclear leukocytes and mononuclear cells.

Six months after infection, the mean spleen weight was $0.18 \mathrm{~g}$. Spleens contained some pigment but the hyperplasia of the red pulp had subsided. The follicles were enlarged and active. Minimal changes remained in the liver apart from a slight hyperplasia of the Kupffer cells.

Doubly infected animals showed a mainly mononuclear cell infiltration of the liver sinusoids which was not seen at this time in mice infected with either the parasite or one of the viruses alone. They also showed a generalized hyperplasia of both the red and the white pulp of the spleen.

One of the six ULV-infected mice with Babesia microti became lymphomatous at 5.5 months and another showed histological evidence of neoplastic involvement when killed at 8 months of age. The $\mathrm{I} 2$ animals infected with RPV and $B$. microti showed no sign of overt lymphoma 6 months later.

\section{DISCUSSION}

The experiments described above show that, in mice infected with either of the oncogenic viruses RPV or ULV, the level and duration of Babesia microti parasitaemia is considerably greater than in mice which have not received these viruses. When Plasmodium berghei yoelii was combined with RPV, or with ULV (Salaman \& Wedderburn, I969; Salaman et al. I969) and $P$. vinckei chabaudi with RPV (F. E. G. Cox \& N. Wedderburn, unpublished) nearly all the virus-infected mice died with overwhelming parasitaemia, whereas most of the mice which had not received virus recovered. Thus these two viruses enhance infections caused by malaria parasites or piroplasms in mice.

Plasmodium berghei yoelii has a predilection for reticulocytes, and an agent which stimulates the production of these cells would be expected to enhance the infection. Babesia microti and $P$. vinckei chabaudi, unlike $P$. berghei yoelii, infect mature red cells preferentially, and an increase in the production of reticulocytes would be likely to depress, rather than enhance, the infection. It appears unlikely, then, that a virus-induced change in the relative numbers of reticulocytes and mature red cells could be the cause of the enhanced protozoan infections recorded in this and previous studies.

Several oncogenic viruses are known to be immuno-depressive (Salaman, 1969, 1970; Notkins, Mergenhagen \& Howard, 1970). RPV sharply depresses the immune response to sheep erythrocytes over a short period early in the infection (Carter et al. 1970) whereas ULV exerts a moderate and gradually increasing effect during the lifetime of the infected animal (Wedderburn, I969). In the present study the Babesia-specific antibody levels detected by the indirect fluorescent antibody technique were similar in the groups of mice which had received viruses and those which had not. However, protective antibody may be only a small part of the total, and this part may conceivably be specifically depressed. Young \& Cox (I97I) found that daily doses of betamethasone caused enhancement of Babesia microti infections comparable with those recorded in this study without any alteration in antibody levels as detected by the indirect fluorescent antibody technique.

Interferon and interferon inducers have inhibitory effects on infections with Plasmodium berghei berghei (Jahiel et al. 1968; Schultz, Huang \& Gordon, 1968). Friend virus, from which RPV was isolated, inhibits the production of interferon by Sendai virus (Wheelock, 
1966). If interferon affects piroplasmosis in the same way as it does plasmodial infections, the enhancement of parasitaemia in virally infected animals might be due, at least in part, to this kind of interaction.

The incidence of Babesia microti in small mammal populations, as estimated by an examination of blood films, has been shown by Young (1970) to be higher than would be expected if the period of patency in nature is only 3 to 4 weeks, as it is in the laboratory. RPV and ULV were isolated from laboratory animals but a number of oncogenic viruses, some of similar type, have been isolated from wild rodents (Rowe, Huebner \& Hartley, 1960; Pope, I96I, I 963; Gardner et al. 197I), as have some non-oncogenic viruses which are immuno-depressive for short periods (Mims \& Wainwright, I968; Osborn, Blazkovek \& Walker, 1968). Prolonged parasitaemias are usually attributed to antigenic variation in the parasite, but the present observations suggest that they could also result from concurrent viral infections which have not been detected because they have not been looked for. It is also possible that the duration of laboratory infections with $B$. microti may sometimes be altered by unrecognized latent virus infections. This might account for the continuous high parasitaemias recorded by Irvin \& Brocklesby (I969) with the same strain of B. microti as used in the present study, but using BSVS mice.

The possible effect of Babesia microti on the development of lymphoma in mice infected with either RPV or ULV has not been investigated fully in the present work. The effects of two other oncogenic viruses, murine sarcoma virus (Harvey) and Moloney virus, are enhanced by concurrent infection with Plasmodium berghei yoelii (Salaman et al. I969; Wedderburn, 1970). Almost all Balb/c mice infected with RPV as young adults develop lymphoma between 6 and 12 months later (Carter et al. 1970 ) and 50 to $80 \%$ of ULV-infected mice develop lymphoma between 5 and 12 months.

There was no evidence of enhanced lymphomagenesis in this study. However, the design of the experiments and the numbers of animals used were not such that this possibility can be excluded.

We wish to thank Dr F. C. Chesterman for histological diagnosis, Dr M. H. Salaman for valuable advice and Mr F. J. Schindler for technical assistance. This work received financial support from the Cancer Research Campaign and the World Health Organization.

\section{REFERENCES}

Carter, R. L., Chesterman, F. C., Rowson, K. E. K., Salaman, M. H. \& Wedderburn, N. (i970). A new virus of minimal pathogenicity associated with Friend virus. II. Histological changes and immunodepressive effect. International Journal of Cancer 5, 103-1 I0.

Cox, F. E. G. (1966). Acquired immunity to Plasmodium vinckei in mice. Parasitology 56, 719-732.

Cox, F. E. G., Crandall, C. A. \& Turner, S. A. (1969). Antibodies detected by the fluorescent antibody technique in mice infected with Plasmodium vinckei and $P$. chabaudi. Bulletin of the World Health Organization 4I, 25I-260.

Cox, F. E. G. \& Young, A. S. (1969). Acquired immunity to Babesia microti and Babesia rodhaini in mice. Parasitology 59, 257-268.

Gardner, M. B., Officer, J. E., Rongey, R. W., Estes, J. D., Turner, H. C. \& Huebner, R. J. (I971). C-type RNA tumour virus genome expression in wild house mice. Nature, London 232, 617-620.

Gleason, N. N., Healy, G. R., Western, K. A., Benson, G. D. \& Schultz, M. G. (1970). The 'Gray' strain of Babesia microti from a human case established in laboratory animals. Journal of Parasitology 56, $1256-1257$.

Irvin, A. D. \& Brocklesby, D. W. (1969). Continuous high parasitaemia in mice infected with Babesia (Nuttallia) microti. Journal of Parasitology 55, 1190. 
JAhiel, R. I., Nussenzweig, R. S., VANDERBERG, J. \& VilCEK, J. (1968). Antimalarial effect of interferon inducers at different stages of development of Plasmodium berghei in the mouse. Nature, London 220 , 7I0-7II.

Mims, C. A. \& WaINWRIGHT, S. (1968). The immunodepressive action of lymphocytic choriomeningitis virus in mice. Journal of Immunology ror, 717-724.

Notkins, A. L., Mergenhagen, S. E. \& Howard, R. J. (1970). Effect of virus infections on the function of the immune system. Annual Review of Microbiology 24, 525-538.

Osborn, J. E., BlaZKoveK, A. A. \& Walker, D. L. (1968). Immunosuppression during acute murine cytomegalovirus infection. Journal of Immunology 100, 835-844.

PeTERs, W. (1965). Competitive relationship between Eperythrozoon coccoides and Plasmodium berghei in the mouse. Experimental Parasitology 16, I 58-166.

Peters, W. (1967). Chemotherapy of Plasmodium chabaudi infection in albino mice. Annals of Tropical Medicine and Parasitology 61, 52-56.

PoPE, J. H. (I96I). Studies of a virus isolated from a wild house mouse Mus musculus and producing splenomegaly and lymph node enlargement in mice. Australian Journal of Experimental Biology 39, 52 I-536.

PoPE, J. H. (1963). Detection of an avirulent virus apparently related to Friend virus. Australian Journal of Experimental Biology 4r, 349-362.

Rowe, W. P., Huebner, R. J. \& Hartley, J. W. (1960). Ecology of a mouse tumour virus. Perspectives in Virology 2, I77-190.

RowsOn, K. E. K. \& PARR, I. B. (1970). A new virus of minimal pathogenicity associated with Friend virus. I. Isolation by end-point dilution. International Journal of Cancer 5, 96-102.

Salaman, M. H. (1963). Attempt to isolate a leukaemogenic virus from urethane-induced leukaemia in mice. Report of the British Empire Cancer Campaign 40, 220-221.

Salaman, M. H. (1969). Immunodepression by viruses. Antibiotics and Chemotherapy 15, 393-406.

Salaman, M. H. (1970). Immunodepression by mammalian viruses and plasmodia. Proceedings of the Royal Society of Medicine 63, I I-15.

Salaman, M. H. \& Flocks, J. (I964). An attempt to isolate a leukaemogenic virus from urethane-induced leukaemia in mice. Report of the British Empire Cancer Campaign 42, 192-193.

Salaman, M. H. \& Wedderburn, N. (1969). Proceedings of the International Congress on Immunity and Tolerance in Oncogenesis, p. 613. University of Perugia.

Salaman, M. H., Wedderburn, N. \& BruCe-ChWATt, L. J. (I969). The immunodepressive effect of a murine plasmodium and its interaction with murine oncogenic viruses. Journal of General Microbiology 59, 383-39I.

Schultz, W. W., HuANG, K. Y. \& Gordon, F. B. (1968). Role of interferon in experimental mouse malaria. Nature, London 220, 709-710.

ShORTT, H. E. \& BLACKIE, E. J. (1965). An account of the genus Babesia as found in certain small mammals in Britain. Journal of Tropical Medicine and Hygiene 68, 37-42.

WEDDERBURN, N. (1969). The action of some oncogenic viruses on immune responses. Ph.D. Thesis, University of London.

WEDDERBURN, N. (1970). Effect of concurrent malarial infection on development of virus-induced lymphoma in Balb/c mice. Lancet ii, III4-III6.

WHEELOCK, E. F. (1966). The effects of nontumor viruses on virus-induced leukaemia in mice: reciprocal interference between Sendai virus and Friend leukaemia virus in DBA/2 mice. Froceedings of the National Academy of Sciences of the United States of America 55, 774-780.

Yoeli, M., Becker, Y. \& BernKopf, H. (1955). The effect of West Nile Virus on experimental malaria infection (Plasmodium berghei) in mice. Harefuah, Jerusalem 49, I16-I19.

Young, A. S. (1970). Investigations on the epidemiology of blood parasites of small mammals with special reference to piroplasms. Ph.D. Thesis, University of London.

YounG, A. S. \& Cox, F. E. G. (1971). The effect of betamethasone on Babesia microti and B. rodhaini infections in rodents. Parasitology 63, 447-453. 